\title{
Relationship between University Level and Employment of Language-Learning Strategies: A Study of EAP Learners
}

\author{
Narjes Ghafournia ${ }^{1}$ \\ ${ }^{1}$ Department of English, Neyshabur Branch, Islamic Azad University, Neyshabur, Iran \\ Correspondence: Narjes Ghafournia, Department of English, Neyshabur Branch, Islamic Azad University, \\ Neyshabur, Iran. Tel: 98-915-313-0060. E-mail: narjesghafournia@yahoo.com
}

Received: December 23, 2013 Accepted: January 20, 2014 Online Published: February 12, 2014

doi:10.5539/elt.v7n3p159 URL: http://dx.doi.org/10.5539/elt.v7n3p159

\begin{abstract}
This study scrutinized the relationship between utilizing language-learning strategies and university levels in reading-comprehension process of language learners in Iran. The participants comprised 406 EAP students at three university levels. The findings reflected significant differences among the students in implementing learning strategies. The students at higher university levels employed overall, direct, and indirect strategies significantly more frequently than the students at the lower stages. The results also revealed that $63 \%$ of the variance in the implementation of learning strategies could be due to the participants' university levels. The findings are of significance because they can help language teachers tailor effective strategic-based language-teaching programs to the academic needs of the students at different stages of learning. The findings can assist language teachers in identifying problematic areas at different stages of learning enabling them to do remedial work with unsuccessful learners.
\end{abstract}

Keywords: language-learning strategies, strategic-based instruction, university level

\section{Introduction}

Most of the systematic researches on language-learning strategies emerged in the 1960s under the influence of significant development in cognitive psychology and some radical reactions to teacher-directed transmission model of education. There has been considerable debate over the changes in institutionalized education and adaptation to learner-centered approaches, in which learners are not proactive, but self-reliant enough to take responsibility for their own learning. Brown (1994) regarded this approach as strategic investment, consisting of a set of procedures that raise learners' awareness about what is involved in learning a second language and enable them to self-direct, organize, and undertake responsibility for learning.

Strategic approach to language learning has encouraged many researchers to explore learning differences in terms of psychosocial variables, including level of language proficiency, learning style, gender, motivation, anxiety, beliefs, learning tasks, and cultural backgrounds (e.g., Carson \& Longhini, 2002; Cohen \& Dörnyei, 2002; Dreyer \& Oxford, 1996; Horwitz et al., 1986; MacIntyre, 2002; Su, 2005; Wharton, 2000). The importance of strategic process of language learning has been also stressed by the earlier researchers due to providing useful insights into the cognitive process of language learning (e.g., Dörnyei, 2005; Ellis, 1994).

As language learning is a complex multidimensional cognitive process, detailed analyses of the factors affecting the strategic process of language learning is of crucial importance. Although many studies have explored the impact of different variables on the strategic process of language learning, many questions remain unanswered. As an example, how university students at different educational levels employ language learning strategies has been rarely surveyed by a systematic approach. Definitely, detailed analysis of strategic processing of language learning enables language teachers to get a clear picture of the cognitive process as well as the overlapping and distinct areas of language learning at different stages. Teachers can also identify learning problems or deficiencies at different stages to take appropriate remedial actions.

Due to ineffective instructional programs at most universities, language learners often run into major problems to comprehend academic materials even at advanced stages of learning. As an example, there exist many postgraduate students having enough linguistic foundation yet unable to comprehend academic texts written in English. The reason may be ineffective employment of language-learning strategies leading to major learning 
difficulties.

The present study aims to analyze the differences in implementing language-learning strategies among Iranian students at different university levels. As improving L2 reading ability is the major focus of many language-teaching programs at universities, the differences in the strategic patterns of the students are explored in the process of reading comprehension. The findings can provide enlightening information as the strategic patterns of language learners are compared, which can reveal the overlapping and distinct areas of strategy use at different stages of learning. The findings can provide useful information about the extent to which success in reading comprehension is reliant on the implementation of language-learning strategies, which can encourage language teachers to take corrective measures to improve the efficacy of instructional reading programs.

\section{Review of Literature}

Earlier researchers have explored the impact of years of language learning on the employment of language-learning strategies (e.g., Ok, 2003; Ramirez, 1986). Ramirez found that years of language learning affected the application of language-learning strategies by 105 students studying French at three high school levels in New York. Ok probed the influence of school year on the employment of language-learning strategies by 325 Korean secondary school students. The findings showed that overall strategy use by language learners did not differ significantly in different school years. However, the third-year students applied compensation and memory strategies more frequently compared to the first-year students who used metacognitive, cognitive, affective, and social strategies more frequently.

Some researchers examined the effect of course level on the strategic behaviors of language learners (e.g., Griffiths, 2003; Politzer, 1983). As an example, Griffiths worked on the relation between course level and strategy use by the speakers of other languages in New Zealand. The findings manifested a positive relationship between the frequency of strategy use and course levels. Similarly, Politzer found that course level significantly influenced selection of learning strategies. The students at higher courses used positive, student-directed, communicative, and functional strategies most frequently. The effect of course level on choosing certain language-learning strategies has been also manifested in other studies (e.g., Ghrib, 2004). Ghrib probed the relation between course level and using learning strategies by 130 Tunisian secondary school students studying at the 6 th and 7 th grades. The study was conducted by using two questionnaires developed by the researcher. The results revealed that course level significantly influenced choice of certain language-learning strategies. The 6th-grade students employed resourcing, avoidance, translation, and borrowing strategies more frequently than did the 7th-grade students who used social, affective, paraphrase, circumlocution, and simplification strategies more frequently.

However, advancement in course level or years of study does not necessarily lead to frequent use of learning strategies. In their study, Cohen and Aphek (1981) reported that learners at different course levels were not significantly different in the use of learning strategies.

The present study aims to probe the probable significant relation between implementation of language-learning strategies and university level among Iranian EAP students. The study seeks the differences in the strategic patterns of Associate Degree, BA, and MA students in Iran. The strategic differences are explored in the process of reading comprehension, which is the major focus of English teaching programs at the universities in Iran. Furthermore, the study seeks the extent to which university level can exert influence on the implementation of language-learning strategies.

The research questions are:

1) Is there any significant relationship between university levels and employing language-learning strategies?

2) To what extent does university level influence employment of language-learning strategies?

\section{Methodology}

\subsection{Participants}

642 students getting Associate Degree, BA, and MA in different disciplines of social sciences participated in this study. They were recruited from Islamic Azad University of Neyshabur in Iran. On the basis of their scores in a reading test, only the students at the intermediate level of reading proficiency were selected. The reason for choosing the intermediate level students was to homogenize them in terms of reading proficiency. Thus, the final sample comprised 406 students doing EAP courses at three university levels of Associate Degree, Bachelor of Arts, and Master of Arts. The participants were males and females, ranging in age from 20 to 30. The frequency of the participants across three university levels is shown in Table 1. 
Table 1. Frequency of the participants

\begin{tabular}{ll}
\hline University Levels & Frequency \\
\hline Associate Degree & 135 \\
Bachelor of Arts & 111 \\
Master of Arts & 160 \\
\hline
\end{tabular}

\subsection{Instruments}

To probe the research questions, the following instruments were utilized in the study.

\subsubsection{Reading Comprehension Test}

A reading test derived from a TOEFL Test was employed in this study. The test consisted of of five reading texts and 50 test items.It was administerd to all the participants. The time alloted to take the test was about 60 minutes.

\subsubsection{Language-Learning Strategy Questionnaire}

The fifth version of Oxford's (1990) Strategy Inventory for Language Learning comprising 50 English statements, contextualizing the implementation of learning strategies in reading comprehension, was administered to the participants. It was organized on a 5-point Likert scale, including five adverbs of frequency. The time dedicated to answer the questionnaire was 25 minutes. It was piloted by a sample of 35 participants. The reliability estimate of the questionnaire was calculated by using Cronbach's alpha formula. The results are displayed in Table 2.

Table 2 . The reliability estimate of learning stategy questionnaire

\begin{tabular}{lll}
\hline Questionnaire & Number of items & Reliability Estimate \\
\hline Learning Strategy & 50 & .930 \\
\hline
\end{tabular}

As manifested in Table 2, the reliability coefficient of the questionnaire was .930 , indicating very small error of measurement.

\subsection{Data Collection Procedures}

Initially, the participants took the test in about 60 minutes. Based on their scores on the reading test, only the participants at intermediate proficiency level were selected as a purposive sample utilized in this study. They filled out the questionnaire in about 25 minutes.

\section{Results and Discussion}

To probe the first reseach question, concerning the significant differences among the participants at different university levels in using language-learning strategies, descriptive statistics were applied. The results are demonstrated in Table 3.

Table 3. Descriptive statistics

\begin{tabular}{|c|c|c|c|c|c|c|c|c|c|}
\hline \multirow{2}{*}{$\begin{array}{l}\text { Learning } \\
\text { Strategies }\end{array}$} & \multirow{2}{*}{ University Levels } & \multirow{2}{*}{$\mathrm{N}$} & \multirow{2}{*}{ Mean } & \multirow{2}{*}{ Std. Deviation } & \multirow{2}{*}{ Std. Error } & \multicolumn{2}{|c|}{$\begin{array}{l}95 \% \text { Confidence } \\
\text { Interval for Mean }\end{array}$} & \multirow{2}{*}{ Mini } & \multirow{2}{*}{ Max } \\
\hline & & & & & & $\begin{array}{l}\text { Lower } \\
\text { Bound }\end{array}$ & $\begin{array}{l}\text { Upper } \\
\text { Bound }\end{array}$ & & \\
\hline \multirow{4}{*}{$\begin{array}{l}\text { Overall } \\
\text { Strategies }\end{array}$} & Associate Degree & 10 & 2.6380 & .36914 & .11673 & 2.3739 & 2.9021 & 2.04 & 3.23 \\
\hline & Bachelor of Arts & 316 & 3.0970 & .47727 & .02685 & 3.0441 & 3.1498 & 1.57 & 4.47 \\
\hline & Master of Arts & 78 & 3.3478 & .48801 & .05526 & 3.2378 & 3.4579 & 2.35 & 4.81 \\
\hline & Total & 404 & 3.1340 & .49257 & .02451 & 3.0859 & 3.1822 & 1.57 & 4.81 \\
\hline \multirow{4}{*}{$\begin{array}{l}\text { Direct } \\
\text { Strategies }\end{array}$} & Associate Degree & 10 & 2.6660 & .30909 & .09774 & 2.4449 & 2.8871 & 2.20 & 3.10 \\
\hline & Bachelor of Arts & 316 & 3.1376 & .48257 & .02715 & 3.0842 & 3.1910 & 1.62 & 4.70 \\
\hline & Master of Arts & 78 & 3.4103 & .54061 & .06121 & 3.2884 & 3.5321 & 2.37 & 5.83 \\
\hline & Total & 404 & 3.1786 & .50815 & .02528 & 3.1289 & 3.2283 & 1.62 & 5.83 \\
\hline
\end{tabular}




\begin{tabular}{llcccccccc}
\hline & Associate Degree & 10 & 2.5970 & .55540 & .17563 & 2.1997 & 2.9943 & 1.83 & 3.39 \\
Indirect & Bachelor of Arts & 316 & 3.0447 & .56151 & .03159 & 2.9826 & 3.1069 & 1.36 & 4.61 \\
Strategies & Master of Arts & 78 & 3.2677 & .61161 & .06925 & 3.1298 & 3.4056 & 1.65 & 4.61 \\
& Total & 404 & 3.0767 & .58170 & .02894 & 3.0198 & 3.1336 & 1.36 & 4.61 \\
\hline
\end{tabular}

As indicated in Table 3, MA students $(\mathrm{M}=3.3478, \mathrm{SD} .=.48801)$ employed overall strategies most frequently. MA students also employed direct as well as indirect strategies more frequently than did BA and associate degree students. Figure 1 demonstrates the relation between university levels and employment of language-learning strategies.

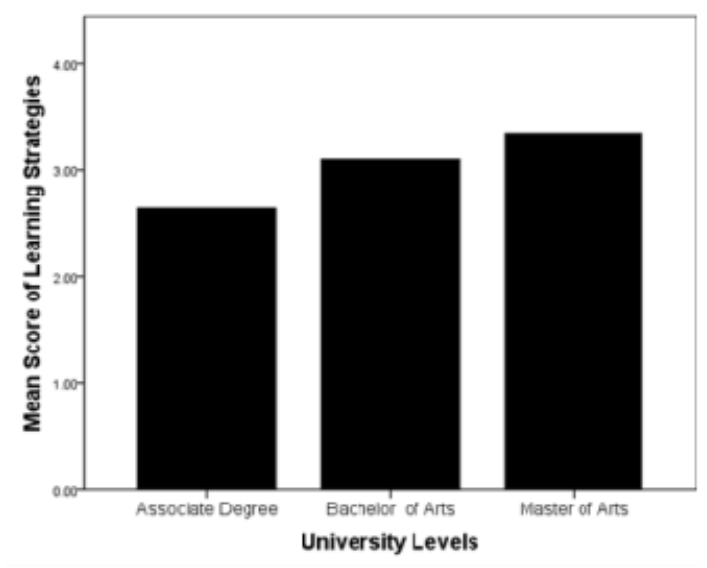

Figure 1. Relation between university levels and employment of language-learning strategies

As depicted in Figure 1, MA students employed language-learning strategies most frequently whereas associate degree students employed language-learning strategies least frequently. BA and MA students were very similar in the mean score of utilizing the strategies. Table 4 indicates the result of a one-way analysis of variance for examining significant differences among the participants' mean scores in employing the strategies.

Table 4. One-way analysis of variance

\begin{tabular}{llccccc}
\hline Learning Strategies & $\begin{array}{c}\text { Sum of } \\
\text { Squares }\end{array}$ & DF & Mean Square & F & Sig. \\
\hline Overall & Between Groups & 6.460 & 2 & 3.230 & 14.183 & .000 \\
Strategies & Within Groups & 91.316 & 401 & .228 & & \\
& Total & 97.776 & 403 & & & \\
\hline \multirow{2}{*}{$\begin{array}{l}\text { Direct } \\
\text { Strategies }\end{array}$} & Between Groups & 7.344 & 2 & 3.672 & 15.224 & .000 \\
& Within Groups & 96.718 & 401 & .241 & & \\
& Total & 104.062 & 403 & & & \\
Indirect & Between Groups & 5.470 & 2 & 2.735 & 8.378 & .000 \\
Strategies & Within Groups & 130.896 & 401 & .326 & & \\
& Total & 136.366 & 403 & & & \\
\hline
\end{tabular}

As reflected in Table 4, significant differences existed among the mean scores of overall $\mathrm{F}(2,401)=14.183$, $\mathrm{p}=.000$; direct $\mathrm{F}(2,401)=15.224, \mathrm{p}=.000$; and indirect strategies $\mathrm{F}(2,401)=8.378, \mathrm{p}=.000$. To make a multiple comparison among the mean scores and locate any significant differences, a Tukey HSD test was utilized. The results are revealed in Tables 5 and 6. 
Table 5. Multiple comparisons among the mean scores

\begin{tabular}{|c|c|c|c|c|c|c|c|}
\hline \multirow{2}{*}{$\begin{array}{l}\text { Dependent } \\
\text { Variable }\end{array}$} & \multirow{2}{*}{$\begin{array}{l}\text { (I) University } \\
\text { Degree }\end{array}$} & \multirow{2}{*}{$\begin{array}{l}\text { (J) University } \\
\text { Degree }\end{array}$} & \multirow{2}{*}{$\begin{array}{c}\text { Mean } \\
\text { Difference } \\
(\mathrm{I}-\mathrm{J})\end{array}$} & \multirow{2}{*}{ Std. Error } & \multirow{2}{*}{ Sig. } & \multicolumn{2}{|c|}{$\begin{array}{l}\text { 95\% Confidence } \\
\text { Interval }\end{array}$} \\
\hline & & & & & & $\begin{array}{l}\text { Lower } \\
\text { Bound }\end{array}$ & $\begin{array}{l}\text { Upper } \\
\text { Bound }\end{array}$ \\
\hline \multirow{6}{*}{$\begin{array}{l}\text { Overall } \\
\text { Strategies }\end{array}$} & \multirow{2}{*}{ Associate Degree } & Bachelor of Arts & $-.45896^{*}$ & .15327 & .008 & -.8195 & -.0984 \\
\hline & & Master of Arts & $-.70982^{*}$ & .16029 & .000 & -1.0869 & -.3328 \\
\hline & \multirow{2}{*}{ Bachelor of Arts } & Associate Degree & $.45896^{*}$ & .15327 & .008 & .0984 & .8195 \\
\hline & & Master of Arts & $-.25086^{*}$ & .06033 & .000 & -.3928 & -.1089 \\
\hline & \multirow{2}{*}{ Master of Arts } & Associate Degree & $.70982^{*}$ & .16029 & .000 & .3328 & 1.0869 \\
\hline & & Bachelor of Arts & $.25086^{*}$ & .06033 & .000 & .1089 & .3928 \\
\hline \multirow{6}{*}{$\begin{array}{l}\text { Direct } \\
\text { Strategies }\end{array}$} & \multirow{2}{*}{ Associate Degree } & Bachelor of Arts & $-.47163^{*}$ & .15774 & .008 & -.8427 & -.1005 \\
\hline & & Master of Arts & $-.74426^{*}$ & .16496 & .000 & -1.1323 & -.3562 \\
\hline & \multirow{2}{*}{ Bachelor of Arts } & Associate Degree & $.47163^{*}$ & .15774 & .008 & .1005 & .8427 \\
\hline & & Master of Arts & $-.27263^{*}$ & .06209 & .000 & -.4187 & -.1266 \\
\hline & \multirow{2}{*}{ Master of Arts } & Associate Degree & $.74426^{*}$ & .16496 & .000 & .3562 & 1.1323 \\
\hline & & Bachelor of Arts & $.27263^{*}$ & .06209 & .000 & .1266 & .4187 \\
\hline \multirow{6}{*}{$\begin{array}{l}\text { Indirect } \\
\text { Strategies }\end{array}$} & \multirow{2}{*}{ Associate Degree } & Bachelor of Arts & $-.44772^{*}$ & .18351 & .040 & -.8794 & -.0160 \\
\hline & & Master of Arts & $-.67069^{*}$ & .19190 & .002 & -1.1221 & -.2192 \\
\hline & \multirow{2}{*}{ Bachelor of Arts } & Associate Degree & $.44772^{*}$ & .18351 & .040 & .0160 & .8794 \\
\hline & & Master of Arts & $-.22298^{*}$ & .07224 & .006 & -.3929 & -.0530 \\
\hline & \multirow{2}{*}{ Master of Arts } & Associate Degree & $.67069^{*}$ & .19190 & .002 & .2192 & 1.1221 \\
\hline & & Bachelor of Arts & $.22298^{*}$ & .07224 & .006 & .0530 & .3929 \\
\hline
\end{tabular}

Table 5 shows significant differences between the means of MA and Associate Degree students $\left(\mathrm{I}-\mathrm{J}=.70982^{*}\right)$ as well as the means of MA and BA students $\left(\mathrm{I}-\mathrm{J}=.25086^{*}\right)$ in using overall strategies. Significant differences also existed between the means of MA and Associate Degree students $\left(\mathrm{I}-\mathrm{J}=.74426^{*}\right)$ as well as the means of MA and BA students $\left(\mathrm{I}-\mathrm{J}=.27263^{*}\right)$ in using direct strategies. Significance differences were found between the means of MA and Associate Degree students $\left(I-J=.67069^{*}\right)$ as well as the means of MA and BA students (I $-\mathrm{J}$ $\left.=.22298^{*}\right)$ in using indirect strategies. Table 6 presents the homogeneity of the means and locates where the means are significantly different.

Table 6. Tukey HSD test for homogeneity of the means

\begin{tabular}{lllc}
\hline University Levels & $\mathrm{N}$ & \multicolumn{2}{l}{ Subset for alpha $=0.05$} \\
\cline { 3 - 4 } & & 1 & 2 \\
\hline & Overall Learning Strategies & & \\
\hline Associate Degree & 10 & 2.6380 & 3.0970 \\
Bachelor of Arts & 316 & & 3.3478 \\
Master of Arts & 78 & & .143 \\
Sig. & & 1.000 & \\
\hline & Direct Strategies & 3.1376 \\
University Levels & & & 3.4103 \\
Associate Degree & 10 & 2.6660 & .114 \\
Bachelor of Arts & 316 & & \\
Master of Arts & 78 & 1.000 & \\
Sig. & & & \\
University Levels & & & \\
\hline
\end{tabular}




\begin{tabular}{llll}
\hline Associate Degree & 10 & 2.5970 & \\
Bachelor of Arts & 316 & & 3.0447 \\
Master of Arts & 78 & & 3.2677 \\
Sig. & & 1.000 & .340 \\
\hline
\end{tabular}

Table 6 presents the homogeneity of the participants' means in utilizing overall, direct, and indirect strategies. No significant differences existed between the means of MA and BA students in using overall $(p=.143)$, direct $(\mathrm{p}=.114)$, and indirect $(\mathrm{p}=.340)$ strategies.

To examine the second research question, a linear regression analysis was utilized. The condensed model is manifested in Table 7. In the analysis, the use of learning strategies was considered as the dependent variable and university level was considered as the independent variable.

Table 7. Regression model

\begin{tabular}{lllll}
\hline Model & $\mathrm{R}$ & R Square & Adjusted R Square & Std. Error of the Estimate \\
\hline & $.250^{\mathrm{a}}$ & .063 & .060 & .47751 \\
\hline
\end{tabular}

Table 7 indicates that the bivariate correlation between utilizing learning strategies and university levels was ( $\mathrm{R}$ $=.250$ ). The findings also indicate that $63 \%$ of the variance in the employment of learning strategies can be concerned with the participants' university levels. Table 8 presents the regression coefficient between the implementation of learning strategies and university levels.

Table 8. Regression coefficients

\begin{tabular}{llllll}
\hline \multirow{2}{*}{ Model } & \multicolumn{2}{l}{ Unstandardized Coefficients } & \multicolumn{2}{l}{ Standardized Coefficients } & \multirow{2}{*}{ Sig. } \\
\cline { 2 - 4 } & $\mathrm{B}$ & Std. Error & Beta & & \\
\hline (Constant) & 2.239 & .175 & & 12.826 & .000 \\
University Levels & .283 & .055 & .250 & 5.179 & .000 \\
\hline
\end{tabular}

As shown in Table 8, the standardized coefficient or Pearson correlation coefficient between the university levels and implementation of learning strategies was (Beta $=.250$ ), which is significant at $p=.000$. The $t$ value $(t$ $=5.179$ ) was significant at $\mathrm{p}=.000$, representing a significant linear relationship between using learning strategies and the participants' university levels. Figure 1 depicts the strength of the relation between the variables. The observed probability is concerned with the participants' university levels acting as the independent variable, and the expected probability is concerned with employment of learning strategies acting as the dependent variable.

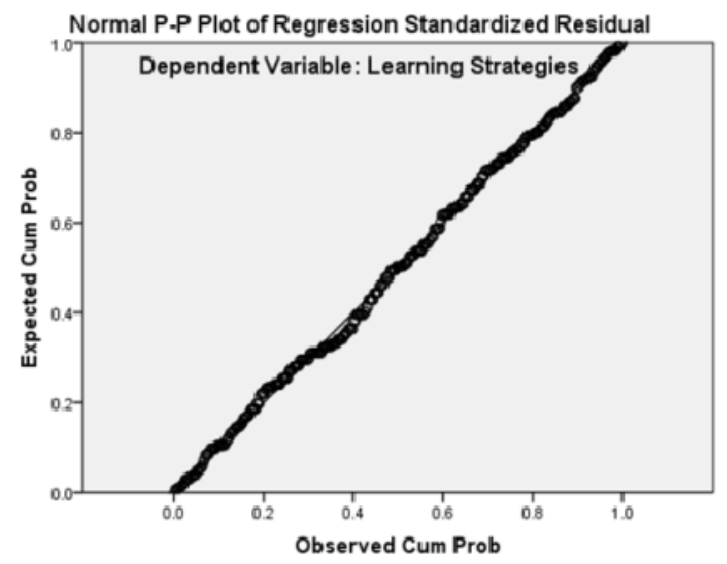

Figure 2. Regression line for the relationship between university levels and employment of learning strategies 
Figure 2 demonstrates that the regression line is nearly steep, showing a strong positive relationship between the participants' university levels and employment of language-learning strategies in reading comprehension process. It means that the students at higher university levels had greater tendencies to apply language-learning strategies. As the findings reflected, MA students used language-learning strategies most frequently due to urgent needs to extract academic information from a number of English sources. The students also adopted a positive attitude toward particular reading instruction programs, in which language teachers give careful consideration to developing linguistic along with strategic competences of L2 learners. Generally, the findings suggest that cognitive process of language learning can be strongly influenced by linguistic as well as non-linguistic factors such as learners' language foundation, academic needs, attitudes, previous language-learning experiences, age, and strategic processing capabilities.

\section{Conclusion}

The study examined the differences among EAP students at different university levels in employing language-learning strategies. In addition, the extent to which the students' university level affected the employment of language-learning strategies was explored in this study. The findings manifested significant relationship between university levels and implementation of language-learning strategies. A positive linear relationship was also revealed between the university levels and employment of language-learning strategies. The results of this study reflected that language learners' strategic processing to comprehend reading texts was strongly dependent on their course levels and academic needs. Although the participants were homogeneous in terms of reading proficiency, they reported different strategic patterns in processing reading texts. The findings can encourage university teachers to adopt a different approach to teach reading effectively based on the linguistic and academic needs of EAP students at different stages of learning. The students at lower stages of learning have insufficient linguistic foundation; therefore, they are unable to use language-learning strategies effectively. Through effective strategic-based instruction, language teachers can narrow the gap between the students at different stages of learning. Despite the great importance of EAP courses at universities, there still exist major problems to resolve. Most of the problems are concerned with the effect of a variety of nonlinguistic factors on the cognitive process of language learning, most of which are largely ignored by language teachers. Thus, further studies are needed to explore cognitive process of language learning from different dimensions.

\section{References}

Bachman, L. F. (1990). Fundamental considerations in language testing. Oxford: Oxford University Press.

Brown, D. H. (1994). Principles of language learning and teaching (3rd ed.). Englewood Cliff, NJ: Prentice Hall Regents.

Canale, M., \& Swain, M. (1980). Theoretical bases of communicative approaches to second language teaching and testing. Applied Linguistics, 1.

Carson, J. G., \& Longhini, A. (2002). Focusing on learning styles and strategies: A diary study in an immersion setting. Language Learning, 52, 401-438.

Cohen, A. D., \& Aphek, E. (1981). Easifying second language learning. Studies in Second Language Acquisition, 3(2), 221-236.

Cohen, A. D., \& Dörnyei, Z. (2002). Focus on the language learner: Motivation styles, and strategies. In N. Schmitt (Ed.), An Introduction to applied linguistics (pp. 170-190). London: Arnold.

Dreyer, C., \& Oxford, R. (1996). Learning strategies and other predictors of ESL proficiency among Afrikaans speakers in South Africa. In R. Oxford (Ed.), Language learning strategies around the world: Cross-cultural perspectives (pp. 231-522). Honolulu: University of Hawaii.

Dörnyei, Z. (2005). The Psychology of the Language Learner. Mahwah, NJ.: Lawrence Erlbaum Associates.

Dreyer, C., \& Oxford, R. (1996). Prediction of ESL proficiency among Afrikaans-speakers in South Africa. In R. Oxford (Ed.), Language learning strategies around the World: Cross-cultural Perspectives. Second Language Teaching and Curriculum Center, University of Hawaii: Honolulu.

Ellis, R. (1994). The Study of Second Language Acquisition. Oxford: Oxford University Press.

Griffiths, C. (2003). Patterns of language strategy use. System, 31, 367-383.

Ok, L. K. (2003). The relationship of school year, sex and proficiency on the use of learning strategies in learning English of Korean junior high school students. Asian EFL Journal, 5(3), 1-36.

Oxford, R. L. (1990). Language learning strategies: What every teacher should know. Boston, MA: Heinle and 
Heinle.

Politzer, R. L. (1983). An Exploratory study of self-reported language learning behaviors and their relation to achievement. Studies in Second Language Acquisition, 54-65.

Ramirez, G. (1986). Language learning strategies used by adolescents studying French in New York schools. Foreign Language Annuals, 19, 131-141.

Ghrib, M. E. (2004). Secondary school students' perceptions of learning difficulties and strategies. The Reading Matrix, 4(2).

Griffiths, C. (2003). Patterns of language strategy use. System, 31, 367-383.

Horwitz, E. K., Horwitz, M. C., \& Cope, J. (1986). Foreign language classroom anxiety. Modern Language Journal, 70, 125-132.

Macintyre, P. D. (2002). Motivation, anxiety, and emotion in second language acquisition. In P. D. Robinson (Ed.), Individual differences in second language acquisition (pp. 45-68). Amsterdam, Netherlands: John Benjamin.

Su, M. (2005). A study of EFL technological and vocational college students' language learning and their self-perceived English proficiency. Electronic Journal of Foreign Language Teaching, 2(1). Retrieved from http://e-flt.nus.edu.sg/Nation

Wharton, G. (2000). Language learning strategy use of bilingual foreign language learners in Singapore. Language Learning, 50(2), 203-243.

\section{Copyrights}

Copyright for this article is retained by the author(s), with first publication rights granted to the journal.

This is an open-access article distributed under the terms and conditions of the Creative Commons Attribution license (http://creativecommons.org/licenses/by/3.0/). 